4. Korniy, L. (2001), The history of Ukrainian music part III. [Istoriya ukrainskoyi muzyky chastyna III], Kyiv-New York, 477 p.

5. Nudgha, G. (1970), The Ukrainian Ballad (From Theory and History of the Genre). [Ukrainska balada (Z teoriyi ta istoriyi ghanru)], Dnipro, Kyiv, 258 p.

6. Pavlyshyn, S. (2000), "Ukrainian folklore in the work of F. Chopin», Frederic Chopin: collection of articles. Scientific Bulletin of the National Music Academy of Ukraine. ["Ukrainskij folklor u tvorchosti F. Chopena», Frederic Chopen: zbirka statej. Naukovyj visnyk Natsionalnoyi Muzychnoyi Akademiyi Ukrainy], Spolom, Lviv, pp. 5-17.

7. Pankratova, V. (1960), Ballad: Musical forms and genres. [Ballada: Muzykalnyje formy $i$ ghanry], Gosizdat, Moscow, 40 .

8. Pastelyak, N. (2004), "Transformation of fame in the piano creativity of B. Lyatoshinsky», Scientific notes. Series: art studies. ["Transformathiya poemnosti u fortepiannij tvorchosti B. Lyatoshynskogo», Naukovi zapysky. Seriya: mystectvoznavstvo], Ternopil, Kyiv, pp. 30-37.

9. Scrabkov, S. (1973), Artistic principles of musical styles. [Chudozhestvennyje princypy muzykalnych stilej], Moscow, 214 p.

10. Sokhor, A. (1968), The aesthetic nature of the genre in music. [Esteticheskaya priroda zhanra v musyke], Music, Moscow, 102 p.

11. Tsukkerman, V. (1964), Musical genres and foundations of musical forms. [Muzykalnyje zhanry i osnovy muzykalny form], Music, Moscow, $159 \mathrm{p}$.

12. Yakubiak, Y. (2000), "About ligatures in the second ballad», Frederic Chopin: collection of articles. Scientific Bulletin of the National Music Academy of Ukraine. ["Pro ligatury u drugij baladi», Frederic Chopen: zbirka statej. Naukovyj visnyk Natsionalnoyi Muzychnoyi Akademiyi Ukrainy], Spolom, Lviv, pp. 249-258.

УДК $78.071 .1(477): 781.68$

ORCID:0000-002-8801-7549

Ірина Коханик, кандидат мистечтвознавства, професор, зав. кафедри теорії музики, Національна музична академія України імені П. І. Чайковського, вул. Архітектора Городецького, 1-3/11, Київ, 02000, Украӥна

Iryna Kokhanyk, Ph.D. in Arts, professor, Head of the Department of Music Theory, Ukrainian National Tchaikovsky academy of music, 1-3/11 Architect Gorodetsky St., Kyiv 02000, Ukraine

\title{
«ГРАВІТАЦЇ̈» ДЛЯ ФОРТЕПІАНО ГАННИ ГАВРИЛЕЦЬ: ПОЛЕ «ТЯЖІННЯ» ІНДИВІДУАЛЬНОГО СТИЛЮ КОМПОЗИТОРА
}

Розглянуто композиційні, ладогармонічні, семантичні особливості фортепіанного циклу «Гравітації» Ганни Гаврилець, у якому реалізується ідея нестійкої рівноваги. Виявлені в аналізі лаконічна манера композиторського письма, класичне відчуття форми, камерність висловлювання, відчуття простору, тонке промалювання деталей, виділення ключової інтонації та її варіантні перетворення, імпровізаційна 
свобода у поєднанні з чіткою логікою композиційно-драматургічного розвитку, вишукана краса мелодизму, породжена романтичним світосприйняттям автора, вже у ранньому творі визначає глибинні риси індивідуального стилю сучасного українського композитора.

Ключові слова: індивідуальний стиль Ганни Гаврилець, ідея нестійкої рівноваги, лейтінтонація, варіантність інтонаційного ядра, динаміка експресивності.

«Gravity» for the piano by Hanna Havrylets: Field of «attraction» of the individual style of the composer. The compositional, harmonic, semantic peculiarities of the piano cycle «Gravitaty» by Hanna Havrylets, are considered, in which the idea of unstable equilibrium is realized. The laconic style of writing, the classical sense of form, the chamber of expression, the feeling of space, the subtle painting of details, the allocation of key intonation, its variant transformations, improvisational freedom combined with the precise logic of compositional and dramaturgical development, the exquisite beauty of melodies, the graphicity of the texture, colorfulness of the sound are the features of the piano cycle «Gravity» by H. Havrylets, creating a field of «attraction» of the composer's style.

Key words: the individual style of Hanna Havrylets, the idea of unstable equilibrium, leitintonation, variability of the intonational core, the dynamics of expressiveness.

«Гравитации» для фортепиано Анны Гаврилец: поле «притяжения» индивидуального стиля композитора. Рассмотрены композиционные, ладогармонические, семантические особенности фортепианного цикла «Гравитации» Анны Гаврилец, в котором реализуется идея неустойчивого равновесия. Выявленные в анализе лаконичная манера композиторского письма, классическое ощущение формы, камерность высказывания, ощущение пространства, тонкая прорисовка деталей, выделение ключевой интонации и ее вариантные преобразования, импровизационная свобода в сочетании с четкой логикой композиционно-драматургического развития, изысканная красота мелодизма, порожденная романтическим мировосприятием автора, уже в раннем произведении определяют глубинные черты индивидуального стиля современного украинского композитора.

Ключевые слова: индивидуальный стиль Анны Гаврилец, идея неустойчивого равновесия, лейтинтонация, вариантность интонационного ядра, динамика экспрессивности. 
«Кожен автор - носій певної космічної ідеї, яку він реалізує у творчості матеріально-звуковим способом.

Йому ичі ідеї спускаються 3-Понад» (Г. Гаврилещ̧ь) [9, с. 45].

Актуальність та новизна. У розвитку української музики на рубежі XX-XXI століть відбувається активне переосмислення і змішування різних тенденцій: новаторство іексперимент на національній основі, органічний синтез фольклорного начала i нових духовних віянь, перенесення на національний грунт знаків стилів попередніх епох, їх «модерне» застосування, раптове співставлення «віддалених у часі» прикмет різних художніх систем [3]. Ці тенденції вплинули на формування індивідуального стилю Ганни Гаврилець - одного 3 лідерів сучасного українського музичного мистецтва, відомого композитора i педагога, лауреата Національної премії України імені Тараса Шевченка, заслуженого діячамистецтв України, члена національної Спілки композиторів України, голови їі Київської організації і т.ін.

Після ряду публікацій кінця 1990-х-початку 2000-х років (О. Берегової, С. Грици, Л. Кияновської, О. Кушнірук, Г. Степанченко та ін. музикознавців - переважно у періодичній пресі та у ряді наукових видань [див. посилання: 5]), творчість Г. Гаврилець останнім часом все частіше виступає як об'єкт наукового розгляду, зокрема, дисертаційних досліджень Т. Сухомлінової [15] і Т. Маскович [11], спрямованих до вивчення хорової духовної спадщини композиторки, яка сьогодні займає провідне місце в іiі творчому доробку. У низці статей наукового характеру висвітлюються різні аспекти творчої діяльності мисткині: О. Бенч [1] та М. Северинової [14], присвячені виявленнюглибинної основи творчості композиторки, ii архетипів - фольклорних та архетипу софійності; О. Беркій [2] - щодо рецепції образу Mater Dolorosa (Stabat Mater Г. Гаврилець); І. Низкогуз [12] - 3 точки зору сучасного композиторського трактування фольклору («Золотий камінь посіємо»); Ю. Пучко [13] - щодо місця духовно-музичних композицій Г. Гаврилець в сучасному хоровому мистецтві України. Вельми інформаційними і глибокими щодо висвітлення особливостей творчого процесу композиторки є науково-публіцистичні статті О. Корчової [4] та А. Луніної [7-9]. Усі ці роботи мають на меті теоретичне усвідомлення надбання композиторки $i$ значною мірою заповнюють прогалини у створенні єдиної картини стильового розвитку іiі творчості. Проте жодне дослідження спеціально не ставить перед собою завдання вивчення процесу стилеутворення, особливосте й 
індивідуального стилю Г. Гаврилець ${ }^{1}$. Ці проблеми були означені автором у статті, присвяченій творчості Г. Гаврилець, де, зокрема, йшлося про те, що «для виведення „формули” індивідуального стилю композитора необхідними передумовами дослідження $є$ такі: а) виявлення детермінант стилю; б) розгляд стильових етапів та жанрових пріоритетів; в) виявлення мовних особливостей, що набувають значення стильових констант» $[5$, c. 171]. Якщо перші дві позиції були певною мірою розглянуті нами у попереднійпублікації, то остання стає предметом розгляду нині.

Метою цієї статті $є$ виявлення мовно-стилістичних особливостей фортепіанного циклу Г. Гаврилець «Гравітації» (1999), в яких простежуються закономірності формування індивідуальної стильової системи композиторки.

Методологія дослідження обумовлена загальним характером роботи та його метою: це, передовсім, текстологічний метод, оскільки об'єктом розгляду $\epsilon$ текст музичного твору; аналітичний метод, спрямований на виявлення його особливостей на різних рівнях музичної організації; метод стильового аналізу, що дозволяє узагальнити отримані результати 3 точки зору еволюції композиторського стилю. Робота спирається також на запропоновані Н. Туровською [16] позиції дослідження раннього періоду композиторської творчості.

Результати. О. Корчова відмічає, що «...залежно від жанрової спрямованості у творчості Г. Гаврилець функціонуєдекілька стильових векторів: фольклорний, <..>, постмодерний і необароковий. Але при цьому незмінним залишається індивідуально-стильове ядро, яке утворюють декілька факторів - мелодичнийі композиційний лаконізм, наскрізний тематичний розвиток, пропорційність форми» [4, с. 12]. Це ядро чітко намітилося вже у ранніх творах композитора. Один з них «Гравітації» для фортепіано - розглядається у даній публікації. Підкреслимо, що на момент їх створення композиторка володіла власним арсеналом музично-виражальних засобів, у яких чітко вгадувався індивідуальний почерк. Можна сміливо стверджувати, що наприкінці 1990-х років Г. Гаврилець вже вступила у пору творчої зрілості.

Весь перший період творчості Г. Гаврилець фактично присвячений написанню камерних композицій для різних інструментів та інструментальних складів. Зокрема, для фортепіано, з яким були пов'язані юнацькі надії композиторастати концертним виконавцем (Варіації для

1 Однією з перших у цьому напрямку стала дипломна робота С. О. Осіпової «Особливості індивідуального композиторського стилю Ганни Гаврилець (на прикладі камерних творів)» (Київ, Київське вище державне музичне училище ім. Р. М. Глієра, 2005; науковий керівник I. М. Коханик). 
фортепіано, 1979, Соната для фортепіано, 1980, Концерт для фортепіано 3 оркестром, 1982, П’єси для фортепіано, 1997, «Гравітації», 1999).

Програмні назви багатьох сучасних творів інколи просто $є$ даниною моді або прагненням композитора привернути увагу до своєї творчості.Спеціальний фізичний термін «гравітація» Г. Гаврилець використала не випадково - тим самим закладаючи ідею «балансування» стабільності й мінливості на всіх рівнях музичного твору (словники й енциклопедії визначають гравітацію як здатність взаємопритягуватися тіл, що мають масу). Задум твору, за словами авторки, виник несподівано і був навіяний спогляданням снігу, що падає. Маленькі, невагомі сніжинки, проживаючи в безкінечному космічному просторі своє коротке життя, тихо опускалися на землю, відчуваючи на собі силу її тяжіння ${ }^{1}$.

«Гравітації» Г. Гаврилець - це невеликий (тривалість звучання близько 7 хвилин) цикл з чотирьох мініатюр (Moderato, Quasi Campane, Risoluto, Misterioso), для характеристики якого дуже підходять слова «мікро-» і «міні-».Тобто свій задум композитор утілює у лаконічній, стислій формі за допомогоюретельно відібраного арсеналу виражальних засобів. Незважаючи на мінімальний обсяг цих засобів, вони мають широкий спектр виразності, який, згідно В. Холопової, можна визначити за «параметрами експресії» [17]. Слідуючи за швидкоплинною, невизначеною, ледь вловимою, витонченою емоцією, композитор намагається надати кожному іï відтінку досконалу, логічно вибудовану форму.

Кожна «Гравітація»має свій настрій і смислове навантаження. Перша виконує роль пролога, друга - синтез саркастичного скерцо (можна провести образну паралель з «Сарказмами» та «Швидкоплинностями» С. Прокоф’єва) i етюда, третя - скерцо, четверта - філософськи узагальнений поліфонічний «епілог». Незважаючи на загальну інтонаційну «ауру», композитор дотримується у кожній частині певних жанрових ознак. У загальному плані можна сказати, що усі мініатюри наближаються до жанрупрелюдії. Цьому сприяють розмірена метроритміка, імпровізаційність, проста форма, притаманна фортепіанним мініатюрам, написаним у жанрі прелюдій.

Проте самобутність твору багато у чому визначається його яскраво сучасним, витончено загостреним звучанням. При створенні власної

\footnotetext{
1 «До речі, я складала цей опус, переживаючи певний стан, який мені навіяла природа. В 1998 році 7 листопада випав сніг. Так іноді буває: зміни погодних умов можуть розбудити творчу фантазію. Причому бажання написати «Гравітації» було таким сильним, що мені довелося перервати роботу над іншим твором - «Canticum». Зізнаюся, що ялюблю працювати одночасно над різними композиціями - великої форми і мініатюрами» [9, с. 42].
} 
концепції композитор орієнтувалася на жанри й стилі музики XX століття, а такожзастосовувала прийоми сучасних технік композиції (серійність, серіальність, атональність, репетитивна техніка) при міцній опорі на класичні традиції (форма композиції в цілому, засоби розвитку музичного матеріалу, синтаксичні особливості). Г. Гаврилець сама вказувала на те, що у «Гравітаціях» використовувала елементи серії [9].

За характером тематичного матеріалуі методамийого розвитку цей твір тяжіє до мінімалізму [10]. Тематичне ядро першої «Гравітації» займає усього один такт, «прогнозуючи» всю музичну композицію. Воно створюється загостреним звучанням ряду інтервалів, але саме септима коливання великої й малої - утворює основний інтонаційний каркас. Другий тематичний елемент (секундова інтонація), що контрастує першому, пов'язаний 3 ним - обидві інтонації $€$ оберненням, відображенням одна одної, являють собою нестійку динамічну єдність. Використання «горизонтальних» i «вертикальних» варіантів, що складаються з шести звуків ( $d, f, b, h, c i s, e-$ неповна «серія»), є алюзією серійної техніки. Композитор будує музичну тканину з витончених мелодичних ліній, але горизонталь непомітно перетікає у вертикаль шляхом нашарування звуків, таким чином, фактура синтезує в собі гомофонно-гармонічний і поліфонічний тип викладу.

В ладо-гармонічній організації вгадується аналогія 3 системою опорних тонів П. Хіндеміта. Проте тут не окремий тон, а цілий інтервал септима $-\epsilon$ основою опорної конструкції. Г. Гаврилецьвикористовує складні акордові побудови, співзвуччя кварто-квінтової структури, що виникають на основі комбінації інтерваліки, заданоїу початкових тематичних утвореннях. У першій п'єсі знаходимо три варіантицих співзвуч: у 4 т. похідне від початкового співзвуччя 31 т. від $d$, у 12 т. висотна «копія» першого співзвуччя, але відcis, у 5 т. - кластер з 5 звуків (малосекундовий) від $h$. Їх розташування у формі відповідає динаміці наростання експресії і поступового повернення до першовитоків.

3 точки зору синтаксису у першій мініатюрі діють принципи повторності і підсумовування. Але розгортання матеріалу, що поєднує його чітке оформлення (двочастинна репризність) 3 рисами імпровізаційності, намічає тенденцію до плинності форми, тяжіння до тяглості, тривалості (за аналогією до деяких прелюдій К. Дебюссі).

Особливістю тематичного розвитку у даній мініатюрі, як і в циклі в цілому, є постійна варіантність інтонаційного ядра та його точний повтор. Метроритмічна сторона надто вільна - у кожному тактізмінюється розмір, немає стабільності, немає опори (гравітація - антигравітація). 
Друга «Гравітація» позбавлена зосередженості, «космічності», що відкриває цикл в експозиційній першій п’єсі. У цій мініатюрі реалізується принцип мотивного розвитку на основі інтонаційного проростання. 3 двох початкових мотивів (широкого септимового, вираженого довгими тривалостями, і короткого секундового - скерцозного акцентного), що подані у взаємодії, народжується основний тематизм твору, що постійно оновлюється у процесі розвитку.

Ритмічна сторона заслуговує особливої уваги, вона $є$ складнішою, ніж у першій «Гравітації», з'являються більш дрібні ноти, репетиції на одному звуці. Капризна або, навпаки, стримана ритміка виграє різними відтінками, примушуючи вслуховуватися у кожен момент звучання.

У фактурному відношенні зберігається вибраний у першій частині принцип утворення музичної тканини через іiї мелодичний ракурс, шляхом нашарування мелодичних звуків, злиття їх у співзвуччя.

Гармонічна сторона тут забарвлюється іншими відтінками застосовуються співзвуччя, що нагадують акорди з арсеналу романтичної гармонії, зокрема, альтеровані, 3 пропущеними тонами.Інтервальна сторона, маючи спільну основу з матеріалом першої частини, породжує також співзвуччя кварто-квінтової структури (т. 11), кластери (т. 26), а також нашарування співзвуч у поліакорди.

Скерцозне начало все ж виявляється превалюючим у даній мініатюрі, а в наступних чотирьох тактах підкреслюється головна септимова інтонація усього твору, що знову нагадує про незавершеність, певну відкритість форми (проста двочастинна 3 маленькою кодою) для подальшого розвитку.

Третя «Гравітація» в образному плані продовжує другу, що підкреслюється насамперед жанровою ознакою скерцо, але воно набуває нових рис - це вже не грайливе скерцо, а гротеск. Стримані співзвуччя перетворюються на уривчасті саркастичні фігури (в їх основі - інтервал секунди у вельми капризному ритмі), що перегукуються з фігуративними віртуозними кварто-квінто-секундовими«сплесками», крізь які знов-таки «просвічує» септимова інтонація. Як і в першій мініатюрі, тут є алюзія до використання елементів серійності (тт. 4, 6, 10). Основний принцип тематичної роботи - не просто варіантність, а більш насичений, ніж у попередніх частинах, мотивний развиток. Початковий імперативний елемент задає імпульс наступному рухові,але він постійно «стримується» паузами $\mathrm{i}$ ферматами, що створюють ефект раптовості, непередбачуваності. У цій частині реалізується «дисонантна» сторона «параметру експресії», оскільки тут присутні всі iї елементи - гострота, стакатність при звуковидобуванні, 
дискретність, розірваність фактури, поєднання широких інтервалів та їх антиподів, поліритмія при поєднанні різних фактурних шарів.

Саме у цій частині лейтінтонації твору повною мірою розкривають свій виразовий потенціал. Повторення цих інтонацій та їх обернень створює картину«гравітації», дає можливість відчути полюси іiі тяжінь з одного боку, це стан стабільності, того, що є незмінним, непорушним взагалі, своєрідна «точка опори», 3 іншого - нестабільність, тяжіння до стрижня, прагнення до завершеності, заспокоєння і водночас намагання відірватися від цього центру. Таким чином втілюється одна 3 основних ідей твору - стан нестійкої рівноваги, що передається через діалектику стійкості - нестійкості, стабільності - нестабільності. Ця ідея виражається i через форму, яка знову базується на варіантному перетворенні вихідного інтонаційного комплексу, де мобільність спонукає до постійного варіантного оновлення тематизму, а стабільність «притягує» до репризних повторів, завершеності, округленості, але 3 «натяком» на відкритість форми.

Самостійність лейтінтервалів розкривається поступово у третій та четвертій п’єсах. Вони вже не просто утворюють співзвуччя, звукоряди, а поруч з цим звучать відверто, акцентовано, у чистому вигляді. Четверта «Гравітація», фінальна, доводить розвиток основної ідеї до логічного завершення. Ці інтервали не розв’язуються, а лише співставляються за ступенем їх експресивності (септими - секунди, секунди - септими, що подаються у різних висотних позиціях).

Четверта п’єса побудована на поліфонічних принципах розвитку тематичного матеріалу. Тема складається 3 «остинатної основи» (з п’яти звуків $c-b$-ges-es-as) і контрапункту, протискладення до неї (e-f-d-a-g), яке $\epsilon$ неточною«копією», що варіюється. Вихідною інтонацією тут також слугує септима, що імітаційно посилюється протискладенням (c-b,e-f). Ця тема, а скоріше іiі складові у кожному з голосів, далі развиваються за законами поліфонічної логіки, з'являючись в оберненні, ракоході. Не відходячи від лейтінтонації, композитор створює новий варіант іiі лінеарного втілення. За композиційною будовою ця частина вкладається у варійовану тричастинність. Вражає закінчення цієї п’єси, де упродовж трьох тактів на ррp «згасає», ніби повисаючи між землею i безоднею, нерозв’язана зменшена терція (енгармонічно рівнавеликій секунді), у якій «згортається» основна ідея усієї композиції. Це ніби одне 3 «вічних» питань, що хвилюють людину, на яке вона не знаходить відповіді. Адже відповідь у тому, що це - «гравітація», закон тяжіння. 
Висновки. Цикл «Гравітації» в цілому можна назвати мікроциклом, що складається 3 п'єс дуже малих за масштабом (паралель з А. Веберном). Простотаі витонченість висловлювання підкоряються чіткій логічній спрямованості твору. Основою циклу є не лейттема, не лейтгармонія, не лейтритм, а лейтінтонаиія, виражена через інтервал, що проходить через весь твір і несе на собі певне семантичне навантаження. Це інтервал септими, який композитор разом з оберненнями подає у різних варіантах та експресивних відтінках.

У гармонії циклу важливе місце посідають акорди змішаної структури, у яких нерідко розрізняється функціональна основа i «колористичні» нашарування. У «Гравітаціях» існує певна «формула» виникнення співзвуч: основний тон + інтервал септим або нони. Якщо цесептима, то ще додається секунда або терція, якщо це нона, то вона $€$ основою співзвуччя, а всередині його звучить терція або секунда.

Композитор мислить в основному лінеарно, але поєднання провідних інтервальних чарунок (септими і секунди), сплітається у складну музичну тканину. Нестійкі, дисонуючі інтервали, що вимагають розв'язання, створюють тяжіння, що відповідає закладеній основній ідеї твору, яка полягає у передачі стану нестійкої рівноваги.

Характеризуючи духовно-музичні хорові композиції Г. Гаврилець, створені вже пізніше «Гравітацій», Ю. Пучко зазначає, що музичну мову композиторки вирізняє «поєднання гостро сучасних дисонансних співзвуч і народнопісенної трихордовості, вільне оперування техніками композиції у поєднанні з фольклорними елементами; вона тонко вимальовує деталі на усіх рівнях музичної організації, суміщуючи графічність музичного письма 3 багатим арсеналом колористичних прийомів» [11, с. 248-249]. Ці ознаки музичного мовлення яскраво виявляються вже у фортепіанних «Гравітаціях» та інших творах Г. Гаврилець, написаних у ранній період творчості, набуваючи, таким чином, рис індивідуального композиторського стилю, який 3 плином часу, залишаючись по суті, яскравим зразком моностилю, органічно вписується у контекст метастилю [див.: 6] сучасної української музики.

Лаконічна манера письма, класичне відчуття форми, камерність висловлювання, відчуття простору, тонке змалювання деталей, виділення ключової інтонації, іiі варіантні перетворення, імпровізаційна свобода у поєднанні 3 чіткою логікою композиційно-драматургічного розвитку, вишукана краса мелодизму, породжені романтичним світосприйняття композитора - ось глибинні риси фортепіанного циклу «Гравітації» А. Гаврилець, що створюють поле «тяжіння» іiї стилю. 
1. Бенч О. Фольклорні архетипи у хоровій творчості Ганни Гаврилецьь//Науковий вісник Національної музичної академії Украӥни ім. П. І. Чайковського. Вип. 75 : Композиторське і сучасне соиіокультурне середовище. Киї, 2009. С. 57-70.

2. Беркій О. Рецепџія образу MaterDolorosa в украӥнському ментальному просторі (на прикладі StabatMater Ганни Гаврилець)//Науковий вісник Національної музичної академії України ім. П. І. Чайковського. Вип. 95: Проблеми музичної інтерпретації. Київ, 2011. C. 270-278.

3. Кияновська Л. Стильові тенденщії у львівській композиторській школі 80-90-х рр.//Мистецькі обрії'99: Альманах: науково-теоретичні праці та публікації/Академія мистеитв Украӥни. Київ: КНВМЦ «СИМВОЛ-Т», 2000. С. 131-141.

4. Корчова О. Музика, написана серием//Музика. 2008. № 2. С. 10-12.

5. Коханик I. Про детермінанти індивідуального стилю Анни Гаврилець//Науковий вісник Національної музичної академї України ім. П. І. Чайковського. Вип. 44: Музика ХХ століття: погляд із ХХІ. Київ, 2006. С. 167-179.

6. Коханик И. Между полистилистикой и метастилем: о стилевых исканиях украинских композиторов на рубеже XX-XXI веков//Київське музикознавство: Музикознавство у діалозі. Вип. 33. Київ; Дюссельдорф, 2010. С. 135-150.

7. Лунина А. Анна Гаврилеи. Аутентика: глубинная почвенность, ментальная характерность, национальная своеобычность... - попытка понять «предел смысловой беспредельности»?//Лунина А. Композитор в зеркале современности: в 2 m. T. 1. Київ; Дух і літера, 2015. С. 85-166.

8. Луніна А. С. «Барбівська коляда»-візитівка Нового року//Музика. 2012. № 1. С. 4-7.

9. Луніна А. Ганна Гаврилеиь: «Успіх для мене - новий твір ...»//Музика. 2014. № 2. С. 40-45.

10. Маркова Д. Явище мінімалізму: принщип мислення та стиль творення//Українське музикознавство. Вип. 31. Київ: Національна музична академія України ім. П. I. Чайковського, 2002. С. 223-232.

11. Маскович Т. М. Хорові твори Ганни Гаврилецьь в руслі «нової сакральності»: дис. ... канд. мистецтвознавства: спеціальність 17.00.03 «Музичне мистецтво»/Одеська національна музична академія ім. А.В. Нежданової. Одеса, 2018. 223 с.

12. Нискогуз I. «Золотий камінь посіємо» Г. Гаврилець в аспекті сучасного композиторського трактування фольклору//Київське музикознавство: зб. статей/Київський інститут музики ім. Р. М. Глієра; Національна музична академія Украӥни ім. П. I. Чайковського. Київ, 2013. Вип. 46. С. 121-128.

13. Пучко Ю. Духовно-музыкальные композичии Анны Гаврилеч в контексте современного хорового искусства Украины//Київське музикознавство: зб. статей/Київський інститут музики ім. Р. М. Глієра; Національна музична академія Украӥни ім. П. I. Чайковського. Київ, 2011. Вип. 36. С. 240-250.

14. Северинова М. Архетип софійності як основа музично-драматургічного потениіалу (на прикладі творчості Ганни Гаврилечь)//Київське музикознавство: зб. статей/Київський інститут музики ім. Р. М. Глієра; Національна музична академія Украӥни ім. П. I. Чайковського. Київ, 2011. Вип. 38. С. 230-238.

15. Сухомлінова Т. П. Хорова творчість Ганни Гаврилецьь у контексті Новітнього

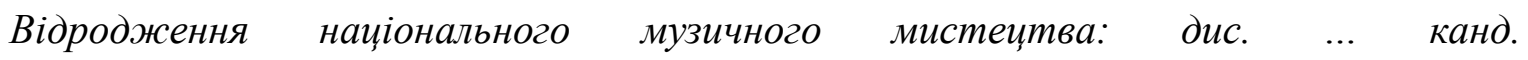
мистецтввознавства: спецііальність 17.00 .03 «Музичне мистецтво»/Харківський національний університет мистецтв ім. І. П. Котляревського. Харків, 2016. 259 с. 
16. Туровська Н. А. Ранній період композиторської творчості як феномен еволюиійного процесу: автореф. дис. ... канд. мистецтвознавства: спеціальність 17.00.03 «Музичне мистеитво»/Львівська національна музична академія ім. М. В. Лисенка. Львів, 2009. 19 с.

17. Холопова В. Формы музыкальных произведений: учеб. пособие.2-е изд., испр. СанктПетербург: Изд-во «Лань», 2001. 496 c.

18. Griffiths P. Modern Music and After. New York: Oxford University Press, 2010. 456 p.

\section{References}

1. Bench, O. (2009) Folk archetypes in choral art by Hanna Havrylets [Folklorni arkhetypy u khorovii tvorchosti Hanny Havrylets] Scientific Herald of Tchaikovsky National Music Academy of Ukraine: Composer's and modern sociocultural environment [Naukovyi visnyk Natsionalnoji muzychnoji akademiji Ukrajiny im. P. I. Chaikovskogo], issue number 75, Kyiv, pp. 57-70 [in Ukrainian].

2. Berkij, O. (2011) The reception of the image of Mater Dolorosa in the Ukrainian mental space (on Hanna Havrylets' Stabat Mater as illustrative material) [Retseptsija obrazu Mater Dolorosa v ukrajins'komu mental'nomu prostori (na prykladi Stabat Mater Hanny Havrylets] Scientific Herald of Tchaikovsky National Music Academy of Ukraine: Problems of musical interpretation [Naukovyi visnyk Natsionalnoji muzychnoji akademiji Ukrajiny im. P. I. Chaikovskogo], issue number 95, Kyiv, pp. 270-278 [in Ukrainian].

3. Kyjanovs'ka, Л. (2000) Style trends in the Lviv composer's school of the 80's and 90's [Styl'ovi tendentsiji u l'vivs'kij kompozytors'kij shkoli 80-90-kh rokiv] Artistic horizons'99: Almanac / National Academy of Arts of Ukraine. Kyiv: "SYMVOL-T", pp. 31-141 [in Ukrainian].

4. Korchova, O. (2008) Music written in the heart [Muzyka, napysana sertsem] Muzyka. № 2. pp. 10-12 [in Ukrainian].

5. Kokhanyk, I. (2006) About the Determinants of the Individual Style by Anna Havrylets [Pro determinanty indyvidual'nogo styliu Anny Havrylets] Scientific Herald of Tchaikovsky National Music Academy of Ukraine: Music of the twentieth century: a view from the XXI century [Naukovyi visnyk Natsionalnoji muzychnoji akademiji Ukrajiny im. P. I. Chaikovskogo], issue number 44, Kyiv, pp. 167-179 [in Ukrainian].

6. Kokhanyk, I. (2010) Between polystylistics and metastyle: about stylistic searches of Ukrainian composers at the turn of XX-XXI centuries [Mezhdu polistilistikoj I metastilem: o stilevyikh iskanijakh ukrainskikh kompozitorov na rubezhe $X X-X X I$ vekov] Musicology of Kyiv:Musicology in Dialogue [Kyjivs'ke muzykoznavstvo: Muzykoznavstvo u dialozi], Kyiv; Dusseldorf: R. Glier Kyiv Institute of Music; Tchaikovsky National Music Academy of Ukraine, Robert-Schumann-Hochschule Dusseldorf Musikwissenschaftliches Institut, issue number 33, pp. 135-150 [in Russian; in English].

7. Lunina, A. (2015) Anna Havrylets. Authenticity: deep soil, mental character, national originality ... - an attempt to understand the «limit» of «semantic boundlessness»? [Autentika: glubinnaja pochvennost', mental'naja kharakternost', natsional'naja svoeobychnost'... - popytka poniat' «predel» «smyslovoj bespredel'nosti»?] Composer in the Mirror of Modernity [Kompozitor v zerkale sovremennosti]: in 2 v. V. 1. Kiev: Dukh $i$ litera, pp. 85-166 [in Russian]. 
8. Lunina, A. (2012) Barbie Carol is a New Year's business card ["Barbivs'kakoliada»vizytivka Novogoroku] Muzyka. № 1. pp. 4-7 [in Ukrainian].

9. Lunina, A. (2014) Hanna Havrylets: "Success for me is a new work...» [Hanna Havrylets: Uspikh dlia mene- novyj tvir...»] Muzyka. № 2. pp. 40-45 [in Ukrainian].

10. Markova, D. (2002) The phenomenon of minimalism: principle of thinking and composing style [Javyshche minimalizmu: pryntsyp myslennja I styl' tvorchosti] Ukrainian musicology [Ukrajins'ke muzykoznavstvo], Kyiv: Tchaikovsky National Music Academy of Ukraine, issue number 31, pp. 223-232 [in Ukrainian].

11. Maskovych, T.M. (2018) The Choral Creativity of H. Havrylets within the Framework of Trend «New Sacredness» [Khorovi tvory Hanny Havrylets v rusli «novoji sacral'nosti»]. Candidate's thesis by specialty 17.00.03 «Music Art». Odessa National Music Academy named afterA. V. Nezhdanova Odessa, 2018. 223 p. [in Ukrainian].

12. Nyskoguz, I. (2013) «We will sow the golden stone» A. Gavrilec's in terms contemporary composer interpretation folklore ["Zolotyjkamin' posijemo» H. Havrylets v aspekti suchasnogo kompozytors'kogo traktuvannia fol'kloru] Musicology of Kyiv [Kyjivs'ke muzykoznavstvo], Kyiv: R. Glier Kyiv Institute of Music; Tchaikovsky National Music Academy of Ukraine, issue number 46, pp. 121-128 [in Ukrainian].

13. Puchko, Ju. (2011) Spiritual and musical compositions of Anna Gavrilets in the context of contemporary choral art of Ukraine [Dukhovno-muzyikalnyie kompozitsii Anny Gavrilets $v$ kontekste sovremennogo khorovogo iskusstva Ukrainyi] Musicology of Kyiv: Culturology and art study [Kyjivs'ke muzykoznavstvo: Kul'turologija $i$ mystetstvoznavstvo], Kyiv: R. Glier Kyiv Institute of Music; Tchaikovsky National Music Academy of Ukraine, issue number 36, pp. 240-250 [in Russian].

14. Severynova, M. (2011) Archetype of Sophia as the basis of musical and dramatic potential (on the example of Hanna Havrylet's creativity) [Arkhetyp sofijnosti jak osnova muzychno-dramaturgichnogo potentsialu (na prykladi tvorchosti Hanny Havrylets)] Musicology of Kyiv: Culturology and art study [Kyjivs'ke muzykoznavstvo: Kul'turologija i mystetstvoznavstvo], Kyiv: R. Glier Kyiv Institute of Music; Tchaikovsky National Music Academy of Ukraine, issue number 38, pp. 230-238 [in Ukrainian].

15. Sukhomlinova, T. P. (2016) Hanna Havrylets' choral work in the context of the Newest Revival of the national musical art [Khorova tvorchist' Hanny Havrylets u konteksti Novitn'ogo Vidrodzhennia national'nogo muzychnogo mystetstva] Candidate's thesis by specialty 17.00.03 «Music Art». Kharkiv National University of Arts named after I. P. Kotlyarevsky. Kharkiv, 2016, 259 p. [in Ukrainian].

16. Turovs'ka, N. A. (2009) Early period of composer's creative work as a phenomenon of evolutionary process [Rannij period kpmpozytors'koji tvorchosti jak fenomen evoliutsijnogo protsesu] Extended abstract of candidate's thesis: 17.00.03 «Music Art» / Lviv National Music Academy named after M. V. Lysenko, Lviv, 19 p. [in Ukrainian].

17. Kholopova, V. (2001) Forms of musical works [Formyi muzyikal'nyikh proizvedenij] Sankt-Peterburg: izd-vo «Lan'», 496 p. [in Russian].

18. Griffiths P. Modern Music and After. New York: Oxford University Press, 2010. 456 p. [in English]. 